\title{
Study on greenhouse soil nitrogen absorption and soil layer transport of different summer catch crops with different planting density in North China
}

\author{
Pei Zhiqiang, Lu Shuchang*, Wang Xi, Hou Kun, Ya Zongjie, Zhang Yu,Wang Dafeng, and Li Xiawen \\ College of Agronomy and Resource Environment, Tianjin Agricultural University, Tianjin 300384, China
}

\begin{abstract}
In order to improve the utilization rate of nitrogen fertilizer and reduce the environmental pollution risk of the nitrogen accumulation in the vegetable field, this study was carried out in the summer leisure period of the greenhouse vegetable production. This experiment designed different planting density treatments in 2017 and 2018, i.e. for catch waxy corn, 3300 plants $/ 667 \mathrm{~m}^{2}$ (WCD1), 5000 plants $/ 667 \mathrm{~m}^{2}$ (WCD2), 6600 plants $/ 667 \mathrm{~m}^{2}$ (WCD3), for forage sweet sorghum, 4500 plants $/ 667 \mathrm{~m}^{2}$ (FSS4), 7000 plants $/ 667 \mathrm{~m}^{2}$ (FSS5), 9000 plants $/ 667 \mathrm{~m}^{2}$ (FSS6) in 2017; and for catch waxy corn, 4500 plants $/ 667 \mathrm{~m}^{2}$ (WCDI), 7000 plants $/ 667 \mathrm{~m}^{2}$ (WCDII), 9000 plants $/ 667 \mathrm{~m}^{2}$ (WCDIII), for forage sweet sorghum, 7000 plants $/ 667 \mathrm{~m}^{2}$ (FSSIV), 10000 plants $/ 667 \mathrm{~m}^{2}$ (FSSV), 14000 plants $/ 667 \mathrm{~m}^{2}$ (FSSVI) in 2018 . The results showed that the biomass and nitrogen absorption of the two catch crops began to improve and then decreased with the increase of planting density. The nitrogen absorption amount of the catch waxy corn and forage sweet sorghum was $22.36 \sim 28.68 \mathrm{~kg} / 667 \mathrm{~m}^{2}, 21.67 \sim 24.39 \mathrm{~kg} / 667 \mathrm{~m}^{2}$, respectively. Different planting density of catch waxy corn and forage sweet sorghum could significantly reduce the total nitrogen content of $0 \sim 30 \mathrm{~cm}$ soil layer and the nitrate nitrogen content of $0 \sim 90 \mathrm{~cm}$ soil layer, for catch waxy corn and forage sweet sorghum, the reduction rate of total nitrogen content in $0 \sim 30 \mathrm{~cm}$ soil layer was $9.6 \% \sim 27.0 \%$, $5.7 \% \sim 23.5 \%$, the reduction rate of nitrate nitrogen content reached $50.0 \% \sim 90.8 \%, 80.1 \% \sim 96.4 \%$, respectively, which effectively controlled the nitrate nitrogen leaching to soil deep layer. Planting catch crops could increase soil urease activity, regulate soil nitrogen transformation. Compared with other treatments, WCDII and FSSV treatment can reduce the initial urease activity and soil nitrate nitrogen content of next crops, which is consistent with the nutrient requirements of broccoli in the early stage of growth. These catch crops planting could reduce the nitrogen environmental risk in the greenhouse soil. Finally, the study proposed that the suitable planting density of catch waxy corn and forage sweet sorghum planted was $6600 \sim 7000$ plants $/ 667 \mathrm{~m}^{2}$, and $9000 \sim 10000$ plants $/ 667 \mathrm{~m}^{2}$, respectively, in the greenhouse summer leisure period. It is more advantageous to improve soil nitrogen absorption and reduce soil nitrogen environmental risks for catch waxy corn.
\end{abstract}

\section{Introduction}

Nitrogen is an important necessary nutrient element for the growth and development of crops, and is also an element that causes eutrophication of water bodies in the ecological environment ${ }^{[1,2]}$, especially in the production system of intensive greenhouse. In recent years, China's intensive facilities had grown in size. In 2015, China's facility vegetable fields area reached $5.35 \times 10^{6}$ ha, accounting for $23.6 \%$ of total vegetable acreage ${ }^{[3]}$. The input of nitrogen fertilizer in the greenhouse production system is several times higher than the nitrogen demand of vegetable crops. Peng et $\mathrm{al}^{[4]}$ pointed out that the nitrogen fertilizer input amount was even more than 10 times the recommended amount in the vegetable fields in the North China Plain. Among the top 10 provinces in China, the average amount of nitrogen fertilizer exceeded $300 \mathrm{~kg} / \mathrm{ha}$, and even reached $500 \mathrm{~kg} / \mathrm{ha}^{[5]}$. The utilization rate of nitrogen fertilizer was only $30 \%$ to $40 \%$. Most of the nitrogen remained in the soil, and the residual amount of nitrogen in the soil increased with the increase of nitrogen application ${ }^{[7,8]}$. When the nitrogen application rate in the vegetable plots was $240 \mathrm{~kg} / \mathrm{ha}$ and $360 \mathrm{~kg} / \mathrm{ha}$, the nitrogen residues were $24.5 \%$ and $47.5 \%{ }^{[9]}$. Nitrogen remaining in the soil easily moved deep into the soil under irrigation and precipitation conditions, and drip washing heavily into the groundwater. Groundwater contaminated by nitrogen migrated with underground runoff to surrounding water bodies, causing water pollution ${ }^{[10]}$. In the summer season of North China from June to September, more than $60 \%$ of the facility greenhouses are in open-top leisure conditions due to high temperature and heat ${ }^{[11]}$, and the summer precipitation is concentrated. Therefore, during the summer leisure period, the vegetable fields became the peak of nitrate leaching, accounting for $22 \%$ to $44 \%$ of the total nitrogen leaching in one year ${ }^{[2]}$. Based on this condition, the introduction of catch crop planting had become a new biological pathway to solve the nitrogen leaching of the facility soil, which could effectively absorb the nitrogen accumulated in the soil and improve the soil ecological environment quality ${ }^{[13]}$.

\footnotetext{
Corresponding author: 1sc9707@163.com
} 
Relevant literatures showed that the catch crop could effectively absorb the nitrogen in the soil leaching solution, the absorption amount could reach 190.05 $\mathrm{kg} / \mathrm{ha}$ (in terms of pure nitrogen), and the nitrate leaching loss could be reduced by $75 \%$ every year ${ }^{[14]}$.Planting sweet corn in the summer leisure period could reduce the amount of nitrate nitrogen in the $0 \sim 100 \mathrm{~cm}$ soil layer of the vegetable field by an average of $290.4 \mathrm{~kg} / \mathrm{ha}^{[15]}$. In recent years, it had become the focus of researchers to solve the problem of nitrogen accumulation in the soil during the greenhouse open-top period, reducing the movement of nitrogen in the lower layer, and improving the greenhouse production efficiency. On one hand, biomass and nitrogen uptake of introduced catch crop was high, on the other, the economic benefits of introduced catch crop were obvious. Studies had shown that $\mathrm{C} 4$ crops are ideal for catch crops, which had the characteristics of large biomass and high temperature tolerance in the short term ${ }^{[16]}$, and could effectively reduce the loss of nitrate in soil. However, systematic studies on planting density, biomass and nitrogen uptake and soil migration between $\mathrm{C} 4$ crops had not been reported. Therefore, this article intended to $\mathrm{C} 4$ crops by planting deep root with different cultivation densities during the summer season. The objectives were to test: if (1)Relationship between different planting density and biomass and nitrogen uptake of $\mathrm{C} 4$ crops during greenhouse recreation; (2)The vertical variation of easily moving nitrogen in soil layers at different depths under different planting densities of $\mathrm{C} 4$ crops during greenhouse recreation; (3)The horizontal and horizontal changes of easily-movable nitrogen in different depths of C4 crops under different planting densities before and after planting. The study provided a reliable biotechnical approach to the control of nitrogen non-point source pollution in facility vegetable fields.

\section{Materials and methods}

\subsection{Test area overview}

The study was conducted at a greenhouse vegetable production base in the northern part of Wuqing, Tianjin, North China. The natural geographical position is E1 16 $57^{\circ} 27.03^{\prime \prime}-116^{\circ} 57^{\prime} 51.87^{\prime \prime}, \mathrm{N} 39^{\circ} 32^{\prime} 8.24^{\prime \prime}-39^{\circ} 32^{\prime}$ 51.81", which belongs to the temperate semi-humid continental monsoon climate. The greenhouse age was about 16 years old. The crops were mainly cultivated with fruits and vegetables in winter and spring, and the crops were mainly leafy vegetables in autumn and winter. In July and August, it was a leisure season. From July to August 2009 to 2016, the average precipitation in the region was above $280 \mathrm{~mm}$, accounting for more than $50 \%$ of the annual average precipitation ${ }^{[17]}$. The sampling time of the test basic soil samples was in early June 2017. The soil type of the test greenhouse was medium-altitude fluvo-aquic soil, the organic matter content and soil nitrogen and phosphorus nutrient content were high, and the soil was light salinization. The soil nutrient status was shown in Table 1.
Table 1. Test surface soil nutrient status.

\begin{tabular}{|c|c|}
\hline Index & Contents \\
\hline Organic matter $\mathrm{g} / \mathrm{kg}$ & 32.42 \\
\hline Total nitrogen $\mathrm{g} / \mathrm{kg}$ & 2.55 \\
\hline Effective phosphorus $\mathrm{mg} / \mathrm{kg}$ & 404.86 \\
\hline Nitrate nitrogen $\mathrm{mg} / \mathrm{kg}$ & 188.33 \\
\hline $\mathrm{pH}$ & 7.42 \\
\hline Salt content $\mathrm{g} / \mathrm{kg}$ & 2.48 \\
\hline
\end{tabular}

\subsection{Test materials}

Waxy corn: In 2017, the planting variety was Xuenuo No. 2, with an average growth period of 95 days, and the row spacing of conventional planting rows in farmland was $40 \mathrm{~cm} \times 50 \mathrm{~cm}$; In 2018 , the planting variety was Aozao 60, and the average growth period was 67 days. The row spacing of conventional plantings in the field was $44 \mathrm{~cm} \times 50 \mathrm{~cm}$. It was suitable for planting during summer leisure period and had high food consumption economic value.

Forage sweet sorghum: the planting variety was sweet variety 2, the average growth period was $135 \mathrm{~d}$, and the row spacing of conventional plantings in the field was $25 \mathrm{~cm} \times 50 \mathrm{~cm}$. It was planted during summer leisure period, with large biomass and high feeding value.

\subsection{Test Processing and Management}

The trials were carried out in the same greenhouse in the winter and spring of 2017 and 2018, after tomato harvest (early June), during summer leisure (from early June to early August). In the 2017 and 2018 trials, six treatments were designed, each treatment was repeated three times. The planting density design was tested at a conventional density of field, a conventional density of about 1.5 times, and a conventional density of 2 times. The test plot area was $30 \mathrm{~m}^{2}(4.7 \mathrm{~m} \times 6.4 \mathrm{~m})$. Since the test routine density in 2017 was based on field planting conditions, there was no peak in the test density biomass results. Therefore, the 2018 test design increased the planting density, as shown in Table 2.

Table 2. Field experiment treatments.

\begin{tabular}{|c|c|c|c|c|}
\hline Years & $\begin{array}{c}\text { Crop } \\
\text { species }\end{array}$ & Treat & $\begin{array}{c}\text { Density / } \\
\text { (plants/ } \\
667 \mathrm{~m}^{2} \text { ) }\end{array}$ & $\begin{array}{c}\text { Plant } \\
\text { spacing } \\
\text { /cm }\end{array}$ \\
\hline
\end{tabular}




\begin{tabular}{|c|c|c|c|c|}
\hline \multirow{6}{*}{2017} & \multirow{3}{*}{$\begin{array}{l}\text { Waxy } \\
\text { corn }\end{array}$} & WCD1 & 3300 & $40 \times 50$ \\
\hline & & WCD2 & 5000 & $27 \times 50$ \\
\hline & & WCD3 & 6600 & $20 \times 50$ \\
\hline & \multirow{3}{*}{$\begin{array}{c}\text { Forage } \\
\text { sweet } \\
\text { sorghum }\end{array}$} & FSS4 & 4500 & $30 \times 50$ \\
\hline & & FSS5 & 7000 & $19 \times 50$ \\
\hline & & FSS6 & 9000 & $15 \times 50$ \\
\hline \multirow{6}{*}{2018} & \multirow{3}{*}{$\begin{array}{l}\text { Waxy } \\
\text { corn }\end{array}$} & WCD I & 4500 & $30 \times 50$ \\
\hline & & WCD II & 7000 & $19 \times 50$ \\
\hline & & WCDIII & 9000 & $15 \times 50$ \\
\hline & \multirow{3}{*}{$\begin{array}{c}\text { Forage } \\
\text { sweet } \\
\text { sorghum }\end{array}$} & FSSIV & 7000 & $19 \times 50$ \\
\hline & & FSS V & 10000 & $13 \times 50$ \\
\hline & & FSSVI & 14000 & $9.5 \times 50$ \\
\hline
\end{tabular}

(Note: WCD was the abbreviation of "Waxy Corn Density" and FSS was the abbreviation of "Forage Sweet Sorghum".)

No fertilizer was applied during the test. The twoyear test was planted at the beginning of June. In addition to the next day's irrigation, no irrigation was carried out during the growth period because of the film uncovering and sufficient precipitation in the current season. Regular weeding was carried out during the growing period, harvested in mid-August, and the two kinds of catch crops were not mature at the time of harvesting, but the waxy corn could be eaten fresh, the fresh biomass was measured at the time of harvesting, and the plant sample was collected to determine the total nitrogen content of the plant. The soil samples of $0 \sim 30$ $\mathrm{cm}, 30 \sim 60 \mathrm{~cm}, 60 \sim 90 \mathrm{~cm}$ soil layers were collected before and after harvesting, and five points were collected for each repeated measurement. The indicators of total nitrogen, nitrate nitrogen and urease were determined. After August 30, broccoli was planted, and the soil samples of $0 \sim 30$ soil layer were collected on September 15 and October 1, respectively, to determine the nitrate nitrogen content and urease activity.

\subsection{Test methods}

\subsubsection{Biomass determination}

At the time of harvest, the actual biomass of fresh plants in the plot was harvested, and then 5 plants with uniform growth were randomly selected, and the roots (roots $0 \sim 20 \mathrm{~cm}$ soil layer root weight) and the aboveground parts were weighed separately, and the ratio of fresh weight to root and shoot was calculated the total root and above-ground fresh weight of the plot. At the same time, it was baked at $105{ }^{\circ} \mathrm{C}$ for $1 \mathrm{~h}$, then dried at $75^{\circ} \mathrm{C}$ to constant weight to prepare corresponding samples, determine the water content of different parts, and finally calculate the dry biomass of different parts (all biomass below was dry biomass).

\subsubsection{Determination of total nitrogen in plants}

Chemical analyses of the post-harvest residue of catch crops were performed after the mineralization of shredded plant material by digestion in concentrated $\mathrm{H}_{2} \mathrm{SO}_{4}$ and $\mathrm{H}_{2} \mathrm{O}_{2}$ applying the following methods: total nitrogen (NTOT) using the Kjeldahl method, and the various parts were calculated. The amount of nitrogen absorbed (1),

Nitrogen absorption=biomass $\times$ total nitrogen content (1)

\subsubsection{Determination of total nitrogen, nitrate nitrogen and urease in soil}

The soil total nitrogen was determined by Kjeldahl method. The soil nitrate nitrogen was measured by ultraviolet spectrophotometer at $210 \mathrm{~nm}$, and the nitrate curve was calculated by the standard curve ${ }^{[18]}$. The soil urease (urease) was based on urea, and the ammonia produced by enzymatic hydrolysis reacts with phenolic compounds to form blue indophenol. The color depth was related to the ammonia content, and the colorimetric was carried out at $578 \mathrm{~nm}$, and then calculated by the standard curve $\mathrm{e}^{[19]}$.

\subsubsection{Statistical analysis}

The experimental data were processed using Excel 2013 method, and statistical analyses were carried out using SPSS 22.0 for Windows software and the results were expressed as mean values. The reduction rate of soil nutrient content below is called pre-planting ratio after planting the same crops in the soil layer.

Reduction rate $=$ (pre-plant nutrient content - nutrient content after planting)/pre-plant nutrient content

\section{Results}

\subsection{Different treatments of two catch crop biomass and soil nitrogen status of absorption greenhouse}

Table 3 showed the soil nitrogen and planting biomass and absorption greenhouse of different treatments of two kinds of catch crops. In 2017, the total biomass and aboveground biomass of the catch waxy corn were increased with the increase of planting density, and the aboveground biomass accounted for more than $88.2 \%$ of the total biomass. And the aboveground and total 
biomass of WCD3 treatment was significantly higher than WCD1 and WCD2 treatments. Root biomass decreased with the increase of planting density, and WCD1 treated root biomass was significantly higher than WCD2 and WCD3 treatment; The nitrogen uptake trend of catch waxy corn was the same as that of biomass. The nitrogen uptake of aboveground nitrogen accounted for more than $88.5 \%$ of total nitrogen uptake, indicating that the increase of planting density of waxy maize increased biomass and nitrogen uptake, but affected root growth. The aboveground biomass accounted for more than $89.1 \%$ of the total biomass, and the aboveground and total biomass of FSS5 and FSS6 was significantly higher than those of FSS1, and the root biomass of that was significantly lower than FSS4 treatment. It indicated that forage sweet sorghum would increase the planting density, which would affect the growth and development of roots. The nitrogen uptake of the aboveground part accounted for more than $91.3 \%$ of the total nitrogen uptake, and the nitrogen treatment trend of different treatments was the same as the biomass. In general, the increase of planting density of the two catch crops could significantly increase crop biomass and nitrogen uptake, and reduce soil nitrogen accumulation in the greenhouse.

In 2018, the total biomass and aboveground biomass of the different treatments of catch waxy corn increased first and then decreased with the increase of planting density, and the aboveground biomass accounted for more than $92.1 \%$ of the total biomass. The total biomass of WCDII treatment was significantly higher than that of WCDI and WCDIII treatments, and the root biomass treatment did not reach significant difference. Nitrogen absorption of catch waxy corn had the same trend as biomass of that, and the nitrogen uptake in the aboveground part accounted for more than $93.3 \%$ of the total nitrogen uptake. The total biomass and aboveground biomass of forage sweet sorghum increased first and then decreased with the increase of planting density, and FSSII treatment was significantly higher than FSSIV treatment, and aboveground biomass accounted for more than $83.5 \%$ of total biomass. The total nitrogen uptake and aboveground nitrogen uptake of FSSV treatment was significantly higher than FSSIV and FSSVI treatments. The nitrogen uptake of roots decreased with the increase of planting density, but the nitrogen uptake of each treatment did not reach significant difference. On the whole, the biomass and nitrogen uptake of the two kinds of catch crops increased first and then decreased with the increase of planting density, and WCDII and FSSV treatments had a great advantage in reducing the nitrogen accumulation in the vegetable fields.

After two years of catch crops density test, the biomass and nitrogen uptake of catch waxy corn in 2018 was lower than that in 2017, and there was no significant difference in the biomass and nitrogen uptake of forage sweet sorghum. Increasing the planting density of the catch crops, the total biomass and nitrogen uptake both increased first and then decreased, and affected the proportion of aboveground biomass to total biomass. WCDII, WCD3, FSS4 and FSSV treatments had higher biomass and nitrogen uptake during the two-year planting, which had a better effect on reducing soil nitrogen accumulation and leaching risk.

Table 3. Biomass and nitrogen uptake of different catch crops in different treatments. Unit: $\mathrm{kg} / 667 \mathrm{~m}^{2}$

\begin{tabular}{|c|c|c|c|c|c|c|c|}
\hline \multirow{2}{*}{ Years } & \multirow{2}{*}{ Treat } & \multicolumn{3}{|c|}{ Biomass } & \multicolumn{3}{|c|}{ Nitrogen absorption } \\
\hline & & Root & aboveground & total & Root & aboveground & total \\
\hline \multirow[t]{3}{*}{2017} & WCD1 & $\begin{array}{l}159.86 \\
\pm 7.19 \mathrm{a}\end{array}$ & $\begin{array}{l}1191.41 \\
\pm 80.66 \mathrm{~b}\end{array}$ & $\begin{array}{l}1351.27 \\
\pm 80.09 \mathrm{~b}\end{array}$ & $\begin{array}{c}1.72 \\
\pm 0.08 \mathrm{a}\end{array}$ & $\begin{array}{c}13.2 \\
\pm 0.86 \mathrm{~b}\end{array}$ & $\begin{array}{r}14.93 \\
\pm 0.82 \mathrm{~b}\end{array}$ \\
\hline & WCD2 & $\begin{array}{c}97.3 \\
\pm 16.66 \mathrm{~b}\end{array}$ & $\begin{array}{l}1555.45 \\
\pm 13.04 \mathrm{~b}\end{array}$ & $\begin{array}{l}1652.75 \\
\pm 20.47 b\end{array}$ & $\begin{array}{c}1.24 \\
\pm 0.21 \mathrm{~b}\end{array}$ & $\begin{array}{c}16.93 \\
\pm 0.22 \mathrm{~b}\end{array}$ & $\begin{array}{c}18.17 \\
\pm 0.39 \mathrm{~b}\end{array}$ \\
\hline & WCD3 & $\begin{array}{r}89.86 \\
\pm 2.65 \mathrm{~b}\end{array}$ & $\begin{array}{r}2448.83 \\
\pm 302.05 \mathrm{a}\end{array}$ & $\begin{array}{r}2538.69 \\
\pm 299.93 \mathrm{a}\end{array}$ & $\begin{array}{r}1.07 \\
\pm 0.03 \mathrm{~b}\end{array}$ & $\begin{array}{r}27.61 \\
\pm 3.18 \mathrm{a}\end{array}$ & $\begin{array}{r}28.68 \\
\pm 3.15 \mathrm{a}\end{array}$ \\
\hline \multirow[t]{3}{*}{2017} & FSS4 & $\begin{array}{r}132.27 \\
\pm 13.73 \mathrm{a}\end{array}$ & $\begin{array}{r}1083.39 \\
\pm 112.49 b\end{array}$ & $\begin{array}{r}1215.66 \\
\pm 126.22 b\end{array}$ & $\begin{array}{r}1.08 \\
\pm 0.11 \mathrm{a}\end{array}$ & $\begin{array}{r}11.38 \\
\pm 1.18 \mathrm{~b} \\
\end{array}$ & $\begin{array}{r}12.47 \\
\pm 1.29 \mathrm{~b}\end{array}$ \\
\hline & FSS5 & $\begin{array}{r}68.62 \\
\pm 2.41 \mathrm{~b}\end{array}$ & $\begin{array}{l}1660.67 \\
\pm 58.41 \mathrm{a}\end{array}$ & $\begin{array}{r}1729.3 \\
\pm 60.82 \mathrm{a}\end{array}$ & $\begin{array}{r}0.37 \\
\pm 0.01 \mathrm{c} \\
\end{array}$ & $\begin{array}{r}19.14 \\
\pm 0.67 \mathrm{a} \\
\end{array}$ & $\begin{array}{r}19.51 \\
\pm 0.69 \mathrm{a} \\
\end{array}$ \\
\hline & FSS6 & $\begin{array}{r}84.83 \\
\pm 6.09 \mathrm{~b}\end{array}$ & $\begin{array}{r}1845.47 \\
\pm 132.43 \mathrm{a}\end{array}$ & $\begin{array}{c}1930.3 \\
\pm 138.52 \mathrm{a}\end{array}$ & $\begin{array}{c}0.61 \\
\pm 0.04 \mathrm{~b}\end{array}$ & $\begin{array}{r}21.06 \\
\pm 1.51 \mathrm{a}\end{array}$ & $\begin{array}{r}21.67 \\
\pm 1.55 \mathrm{a}\end{array}$ \\
\hline
\end{tabular}




\begin{tabular}{|c|c|c|c|c|c|c|c|}
\hline 2018 & WCD I & $\begin{array}{r}78.94 \\
\pm 13.08 \mathrm{~b}\end{array}$ & $\begin{array}{l}1611.44 \\
\pm 45.09 \mathrm{a}\end{array}$ & $\begin{array}{l}1690.38 \\
\pm 50.48 \mathrm{~b}\end{array}$ & $\begin{array}{r}0.67 \\
\pm 0.12 \mathrm{a} \\
\end{array}$ & $\begin{array}{r}18.7 \\
\pm 0.91 \mathrm{a} \\
\end{array}$ & $\begin{array}{r}19.37 \\
\pm 1.02 \mathrm{~b} \\
\end{array}$ \\
\hline & WCD II & $\begin{array}{r}151.40 \\
\pm 51.85 \mathrm{a}\end{array}$ & $\begin{array}{r}1770.34 \\
\pm 132.82 \mathrm{a}\end{array}$ & $\begin{array}{l}1921.74 \\
\pm 96.96 \mathrm{a}\end{array}$ & $\begin{array}{c}1.49 \\
\pm 0.56 \mathrm{a}\end{array}$ & $\begin{array}{r}20.87 \\
\pm 1.46 \mathrm{a}\end{array}$ & $\begin{array}{r}22.36 \\
\pm 1.16 \mathrm{a}\end{array}$ \\
\hline & WCDIII & $\begin{array}{r}87.20 \\
\pm 5.72 \mathrm{ab}\end{array}$ & $\begin{array}{l}1181.63 \\
\pm 33.73 \mathrm{~b}\end{array}$ & $\begin{array}{l}1268.83 \\
\pm 39.44 \mathrm{c}\end{array}$ & $\begin{array}{c}1.05 \\
\pm 0.07 \mathrm{a}\end{array}$ & $\begin{array}{r}15.22 \\
\pm 0.47 \mathrm{~b}\end{array}$ & $\begin{array}{r}16.27 \\
\pm 0.54 \mathrm{c}\end{array}$ \\
\hline 2018 & FSSIV & $\begin{array}{r}259.18 \\
\pm 45.53 \mathrm{a}\end{array}$ & $\begin{array}{l}1333.62 \\
\pm 27.21 \mathrm{~b}\end{array}$ & $\begin{array}{l}1592.80 \\
\pm 60.02 \mathrm{~b}\end{array}$ & $\begin{aligned} & 1.81 \\
\pm & 0.31 \mathrm{a}\end{aligned}$ & $\begin{array}{r}18.67 \\
\pm 2.11 \mathrm{~b}\end{array}$ & $\begin{array}{r}20.48 \\
\pm 1.96 \mathrm{~b}\end{array}$ \\
\hline & FSS V & $\begin{array}{r}315.77 \\
\pm 37.34 \mathrm{a}\end{array}$ & $\begin{array}{r}1598.56 \\
\pm 127.44 \mathrm{a}\end{array}$ & $\begin{array}{r}1914.33 \\
\pm 163.48 \mathrm{a}\end{array}$ & $\begin{array}{c}1.82 \\
\pm 0.08 \mathrm{a}\end{array}$ & $\begin{array}{r}22.57 \\
\pm 1.63 \mathrm{a}\end{array}$ & $\begin{array}{r}24.39 \\
\pm 1.71 \mathrm{a}\end{array}$ \\
\hline & FSSVI & $\begin{array}{r}258.92 \\
\pm 16.81 \mathrm{a}\end{array}$ & $\begin{array}{l}1522.23 \\
\pm 49.93 \mathrm{a}\end{array}$ & $\begin{array}{c}1781.15 \\
\pm 62.23 \mathrm{ab}\end{array}$ & $\begin{array}{c}1.36 \\
\pm 0.09 \mathrm{a}\end{array}$ & $\begin{array}{r}18.76 \\
\pm 0.90 \mathrm{~b}\end{array}$ & $\begin{array}{r}20.11 \\
\pm 0.96 \mathrm{~b}\end{array}$ \\
\hline
\end{tabular}

Note: Different letters in the same column of the same species indicate a difference of $5 \%$ significant level.

\subsection{Effects of different treatments of two kinds of catch crops on soil nitrogen in the greenhouse}

\subsubsection{Greenhouse soil total nitrogen}

The soil total nitrogen content of the surface layer of the greenhouse before and after the catch crops was shown in Fig 1. In 2017, WCD2 treatment of catch waxy corn could significantly reduce the total nitrogen content of the greenhouse soil, the reduction rate was $15.6 \%$, and the total nitrogen content of WCD1 and WCD3 treatments was also reduced, but it did not reach significant difference. FSS5 and FSS6 treatments of forage sweet sorghum significantly reduced soil total nitrogen content, and the reduction rates were $18.8 \%$ and $23.5 \%$, respectively, but there was no significant difference between the two treatments. It was indicated that the increase of the planting density of forage sweet sorghum could significantly reduce the total nitrogen content of the greenhouse soil.

In 2018, the different treatments of the two kinds of catch crops could significantly reduce the total nitrogen content of the greenhouse soil. The reduction rate of total nitrogen content in the greenhouse soil at different density of catch waxy corn was $17.7 \% \sim 27.0 \%$. The reduction rate of total nitrogen content in the surface layer of forage sweet sorghum was $15.5 \% \sim 23.2 \%$. However, there was no significant difference between the different treatments.

From the perspective of planting two years of catch crops, WCD2, WCDI, WCDII, WCDIII, FSS5, FSS6, FSSIV, FSSV, FSSVI treatments could significantly reduce the total nitrogen content of the greenhouse soil, which is better for reducing the soil nitrogen environmental risk of the greenhouse.

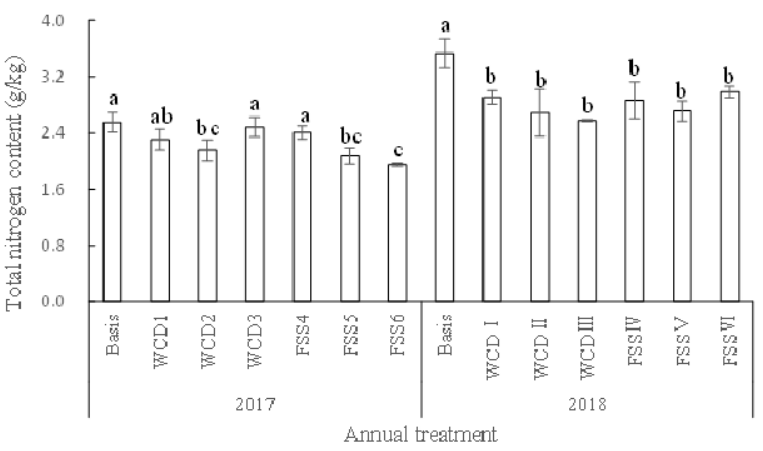

Fig.1. Total nitrogen content in surface soil before and after planting with different crops

\subsubsection{Vertical distribution of soil nitrate nitrogen in greenhouse}

As shown in Figure 2 and 3. In 2017, planting two kinds of catch crops could significantly reduce the nitrate content of the soil of the greenhouse. The reduction rate of nitrate nitrogen content in $0 \sim 30 \mathrm{~cm}, 30 \sim 60 \mathrm{~cm}$ and $60 \sim 90 \mathrm{~cm}$ soil layers was $79.9 \% \sim 90.8 \%, 49.6 \% \sim 59.7 \%$, $29.6 \% \sim 42.0 \%$, respectively. The different rates of nitrate-nitrogen content in the soil of the greenhouse were $84.4 \% \sim 96.4 \%, \quad 54.2 \% \sim 69.6 \%, \quad 25.2 \% \sim 40.0 \%$, respectively. This showed that planting catch crops could significantly reduce the mobile nitrogen content in the greenhouse soil, thereby reduce the nitrogen environmental risk of the greenhouse soil.

In 2018, the different treatments of the two kinds of catch crops could significantly reduce the nitrate nitrogen content in the surface soil. The reduction rate of WCDIII treatment was the highest, which was $90.5 \%$, followed by FSSV treatment, which was reduced by $86.8 \%$, but the treatment did not reach significant difference. The treatments of the two kinds of catch 
crops in $30 \sim 60 \mathrm{~cm}$ soil layer were significantly lower than those before planting. The nitrate content of each treatment of catch waxy corn and forage sweet sorghum decreased by $38.0 \% \sim 69.9 \%$ and $46.7 \% \sim 69.2 \%$, respectively. The content of nitrate nitrogen in soil of $60 \sim 90 \mathrm{~cm}$ soil layer of WCDIII and FSSV treatments was significantly lower than that before planting, which was decreased by $39.9 \%$ and $45.7 \%$, respectively. WCDI treatment increased, indicating that soil nitrate nitrogen had downward leaching.

According to the comprehensive two-year experiment, the reduction of soil nitrate nitrogen content in the lower facilities in 2018 was not obvious in 2017. Probably because of the large rainfall in 2018, the greenhouse vegetable fields were soaked in rain, that caused the upper layer of nitrate nitrogen to move to the lower layer. The each treatment of two kinds of catch crops in 2017 and WCDII, WCDIII, FSSIV and FSSV in 2018 could significantly reduce the nitrogen content of the soil in the greenhouse, and control the soil nitrate nitrogen leaching in the greenhouse, thereby reduce the nitrogen pollution of the greenhouse soil.

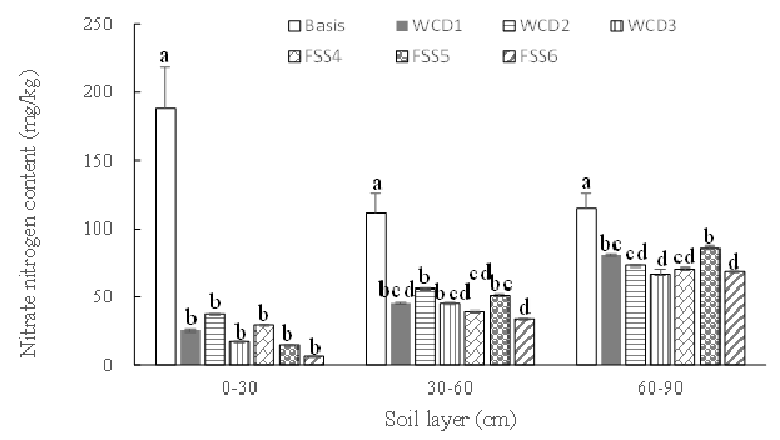

Fig.2. Nitrate nitrogen content in each soil layer before and after planting of different crops (2017Year)

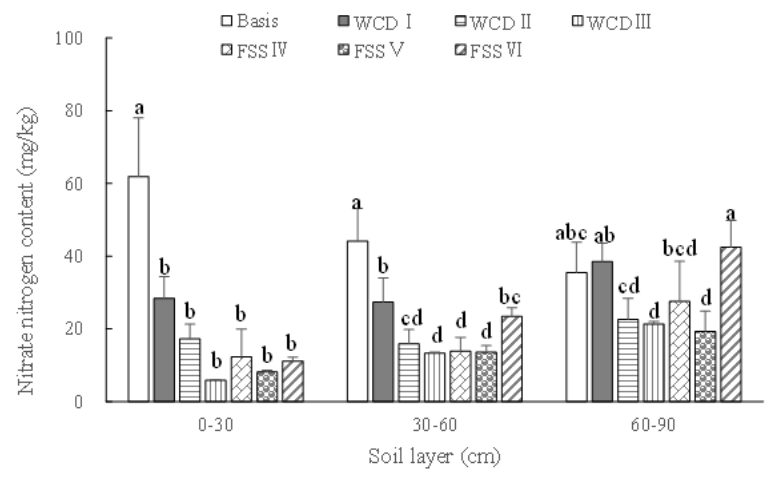

Fig.3. Nitrate nitrogen content in each soil layer before and after planting of different crops (2018Year)

\subsection{Soil urease activity before and after planting of crops and the status of soil surface nitrate nitrogen in the early stage of catch}

Soil urease is involved in soil nitrogen transformation, it provides a nitrogen source for crop growth ${ }^{[20]}$. Qiu
Liping et $\mathrm{al}^{[21]}$ showed that urease was significantly positively correlated with soil fertility. As shown in Figures 4 and 5, the soil urease activity of the two kinds of catch crops increased at different densities in 2018, but it was not obvious. When the broccoli was planted for half a month, WCDII and FSSII treatments had lower urease activity than other treatments, and the nitrate nitrogen content was significantly lower than other treatments. After one month of colonization, the soil urease activity of WCDII and FSSV treatment increased, and the nitrate nitrogen content did not decrease significantly, which could provide quick-acting nitrogen fertilizer for the late growth of broccoli. On the whole, WCDII and FSSV treatments could reduce the urease activity and soil nitrate nitrogen content in the early stage of sorghum, which was consistent with the low nutrient demand in the early growth stage of broccoli, which reduced the nitrogen environmental risk of the greenhouse.

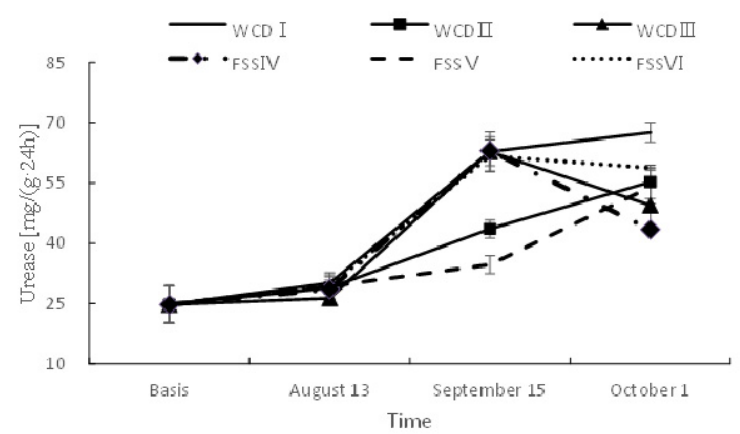

Fig. 4. Soil urease activity in different treatments (2018Year)

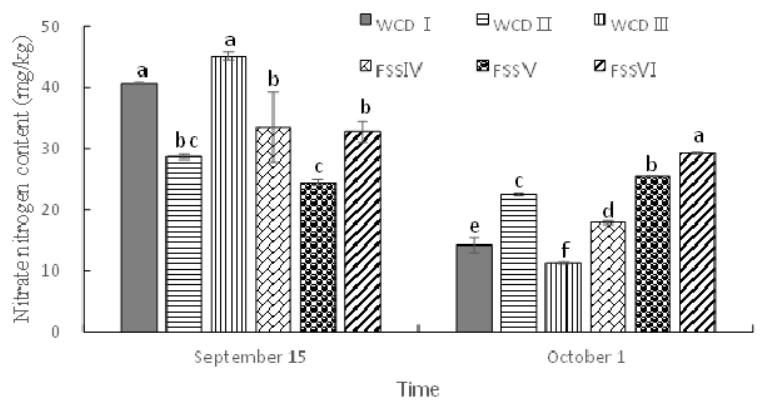

Fig.5. Status of soil nitrate nitrogen in the early stage of alfalfa after different treatments (2018Year)

\section{Discussion}

\subsection{Biomass and nitrogen absorption}

Reasonable close planting of crops was the basis for forming a good reproductive group and exerting group productivity ${ }^{[22]}$. Relevant data showed that sorghum increased grain yield and biomass yield with planting density in the planting density range of 3000 plants $/ 667 \mathrm{~m}^{2} \sim 7000$ plants $/ 667 \mathrm{~m}^{2[23,24]}$.In this experiment, the biomass of catch waxy corn and forage sweet 
sorghum increased first and then decreased with the increase of planting density, and the suitable planting density was higher than that of field planting density in high-fertility vegetable field. The biomass and nitrogen absorption of catch waxy corn in 2018 was lower than in 2017 , which might be caused by differences in planting varieties. Ren et $\mathrm{al}^{[25]}$ showed that sweet corn grew rapidly, it had large biomass and strong ability to absorb nitrogen, and the nitrogen uptake could reach $13.71 \sim 16.41 \mathrm{~kg} / 667 \mathrm{~m}^{2}$. After two years the test, the planting density of catch waxy corn was increased, the nitrogen absorption reached $22.15 \sim 28.68 \mathrm{~kg} / 667 \mathrm{~m}^{2}$. The planting density of forage sweet sorghum was increased, and the nitrogen absorption reached 21.67 21.89 $\mathrm{kg} / 667 \mathrm{~m}^{2}$, which was higher than the normal density of the field to grow nitrogen uptake. Therefore, this study played an important role in obtaining a high biomass and reducing the environmental risk of nitrogen in the vegetable planting field.

\subsection{Catch crops and soil nitrogen}

Roots were the main organs for crops to absorb nutrients, and their distribution, surface area and vigor were closely related to nitrogen absorption and absorption range ${ }^{[9]} . J i$ Yanzhi's research found that corn and sorghum were deep root crops, and their $0 \sim 100 \mathrm{~cm}$ root length accounted for more than $91.0 \%$ of the total root length of $0 \sim 150 \mathrm{~cm}^{[26]}$. The roots grew downward to absorb residual nitrogen in the soil, effectively reducing the amount of nitrate nitrogen accumulated in the soil ${ }^{[27-}$ ${ }^{29]}$.Planting the crops as shown in Figure 3 could significantly reduce the nitrate content of each soil layer, which was consistent with the Guo R' research ${ }^{[30]}$. However, the content of nitrate nitrogen in the soil under the soil in Figure 4 was not significantly different, which might be caused by nitrate nitrogen leaching, or might be caused by root growth and development ${ }^{[31]}$. The study showed that catch crops planting could reduce the total nitrogen content of the soil surface, the absorption of nitrate in the soil decreased with decreasing, which was consistent with the Kristensen'research ${ }^{[32]}$. The relationship between nitrogen absorption and surface total nitrogen reduction was inconsistent, so an isotope tracer test should also be performed.

\subsection{Catch crops and soil urease}

Related studies had found that the summer planting catch crops could increase soil urease activity, and help to improve soil nitrogen transformation ${ }^{[33,34]}$. This present study planting catch crops could reduce the soil total nitrogen content, soil urease activity had increased consistent results. Filling crops could change the amount and activity of soil enzymes in soil microbes and improve soil ecological environment ${ }^{[35-37]}$. After this experiment, the increase of soil surface nitrate nitrogen in the vinegar planting for half a month was consistent with the study of Tian $\mathrm{Y}^{[38]}$. However, WCDII and FSSV treatments remained at a lower level than other treatments. After one month of colonization, the content of nitrate nitrogen in WCDII and FSSV treatments was not significantly reduced, which was consistent with the low nutrient requirement in the early growth stage of broccoli, and provided effective nitrogen for the late growth of broccoli.

\section{Conclusions}

5.1 Both the biomass and nitrogen absorption of the two cropping crops increased first and then decreased with the increase of planting density. The suitable density of catch waxy corn in the vegetable field was 6600 7000 plants $/ 667 \mathrm{~m}^{2}$, and the nitrogen absorption was $22.36 \sim 28.68 \mathrm{~kg} / 667 \mathrm{~m}^{2}$. The suitable planting density of forage sweet sorghum was $9000 \sim 10000$ plants $/ 667 \mathrm{~m}^{2}$, and the nitrogen absorption was $21.67 \sim 24.39 \mathrm{~kg} / 667 \mathrm{~m}^{2}$. 5.2 Increasing the planting density of catch waxy corn and forage sweet sorghum could significantly reduce the total nitrogen content in the soil surface and the nitrate content in each soil layer. The reduction rates of total nitrogen content in the soil surface were 9.6\% 27.0\% and $5.7 \% \sim 23.5 \%$, respectively. The reduction rates of surface nitrate nitrogen content were $50.0 \% \sim 90.8 \%$ and $80.1 \% \sim 96.4 \%$, respectively.

5.3 Catch crops planting could increase soil urease activity, regulate soil nitrogen transformation, reduce soil nitrogen content, and reduce nitrogen loss caused by low nutrient demand in the early stage of post-crop crop growth, and then reduce nitrogen environmental risk.

\section{Acknowledgments}

This work was financially supported by 'Study on the influence factors of high-efficiency growth of characteristic crops and the optimization model of supporting cultivation techniques' of 'University leadership training program' project in Tianjin(J01009030705), Tianjin key R \& D plan scientific and technological support key project 'Integrated control and application of integrated environmental risks of nitrogen and phosphorus in protected farmland and soil quality improvement technology' (19YFZCSN00290), and national key R \& D project 'Integrated demonstration of soil remediation and pollution control technology for high nitrogen and phosphorus residues'(2016YFD0801006). Thanks for the support of these projects.

\section{References}

1. P. Marschner, Marschner's mineral nutrition of higher plants.135-136(Third Edition,Beijing: Science Press,2013)

2. H. Zhang, C. Lin, P. Lei, B.Q. Shan, Y. Zhao, Acta Scientiae Circumstantiae,35, 8(2015)

3. L.Y. Kang, The influence of summer catch crop on soil nitrogen transformation and leaching in greenhouse vegetable.(Beijing: China Agricultural University, 2017) 
4. Y. J. Peng, X.R. Hao, Y.Z. Ji, L. Wang, C.L. Ren, X.L. Ju, L.J. Zhang, Scientia Agricultura Sinica,48, 9 (2015)

5. Q. Chen, F.S. Zhang, Theory and practice of comprehensive management of vegetable nutrient resources.(Beijing: China Agricultural University Press, 2007)

6. Z.C. Wang, Effects of soil nitrate nitrogen accumulation and dry-wet alternating process in farmland.(Beijing: China Agricultural University, 2006)

7. X.T. Ju, F.S. Zhang, Ecology and Environment,12, 2 (2003)

8. P. Dong, C.J. Zhang, Z.P.NPeng, N.N. Wang, T.K. Zhao, Journal of Plant Nutrition and Fertilizer, 22,6(2016)

9. A.K. Xie, Nitrate Accumulation Related Control Strategies in the protected field of Beijing Suburb. (Chinese Academy of Agricultural Sciences, 2010.)

10. L.J. Zhang, X.X. Ju, F.S. Zhang, Z.P. Peng, Scientia Agricultura Sinica,40,9(2007)

11. B. Xi, J.Z. Zhang, L.M. Yan, H.B. Liu,Journal of Agro-Environment Science, 30,1(2011)

12. H.M. Yu, Water Drainage and Nitrate leaching of Vegetable Field under Water and Nitrogen management,15-75(Beijing:China Agricultural University, 2005)

13. Y.Q. Tian, X.Y. Zhang, J. Liu, Plant and Soil,339, $1 / 2(2011)$

14. A. Gustafson, S. Fleischer, A. Joelsson, Ecological Engineering, 14,4(2000)

15. W.S. He, Y.M. Gao, J.L. Wang, J.Q. He, L. Wang, J.Z. He, Journal of Agricultural Sciences,32,1(2011)

16. F.F. Wen, B. Han, Y.Y. Yu, J.F. Liang, Q. Jin, J.Y. Liu, W. Ji, M.X. Qi, China Agricultural Technology Extension,31,4(2015)

17. Tianjin Municipal Bureau of Statistics, Tianjin Survey Team of National Bureau of Statistics. Tianjin Statistical Yearbook(2009-2016).(Beijing: China Statistics Press, 2010-2017)

18. Bao Shidan. Analysis of Soil Agrochemical (3rd Edition) [M]. Beijing: China Agriculture Press, 2000.

19. S.Y. Guan, Soil enzymes and their research methods. (Beijing: Agricultural Press, 1996)

20. J. Gao, B. Xiong, W. Lu, Z. Zhai, B. Jiang, Z.Q. LI, X.T.Xu, Y.Y. Li,Journal of Maize Sciences,24, 4(2016)

21. L.P. Qiu, J. Liu, Y.Q. Wang, H.M. Sun, W.X. He, Plant Nutrition and Fertilizer Science, 10,3(2004)

22. P.Y. Zhu, Y.N. Cheng,Beijing Agricultural Sciences, 13,1(1995)

23. N. Yang, Y.C. Ding, X.Y. Jiao, J.S. Wang, E.W. Dong, L.G. Wang, P. Wu, Journal of Agronomy,3, 7 (2013)
24. Y.J. Yu, X.Q. Guo, G.H. Xie, S.J. Yang, L.A. Niu, R.H. Lv,Journal of China Agricultural University, 14,5(2009)

25. Z.H. Ren, H.F. Li, Q. Chen, X.L. Li,Transactions of the Chinese Society of Agricultural Engineering,22, 9 (2006)

26. Y.Z. Ji,Catch crop control soil nitrogen accumulation and leaching in greenhouse(Baoding: Hebei Agricultural University, 2010)

27. X. Yin, X.X. Wang, L.J. Zhang, Y.X. Ni, C.L. Ren, X.T. Ju, Y.Z. Ji,Journal of Agricultural Resources and Environment,32, 3 (2015)

28. K.P. Lu, J. Min, W.M. Shi, H.L. Wang, Acta Pedologica Sinica,50,2 (2013)

29. E. Valkama, R. Lemola, H. Känkänen, E. Turtola, Agriculture, Ecosystems and Environment,203 (2015)

30. R. Guo, X. Li, P. Christie,Plant and Soil,313,1/2 (2008)

31. J.B. Fan, Y.L. Zhang, X.Y. Wan, Q.R. Shen,Chinese Agricultural Science Bulletin,2 (2007)

32. H.L. Kristensen, K. Thorup-Kristensen, Soil Science Society of America Journal,68(2004)

33. F.Z. Wu, X. Guo, S.W. Liu, X.G. Yi Z.H. Zhou, Journal of Northeast Agricultural University,45,10 (2014)

34. A. Piotrowska-Dlugosz, E. Wilczewski, Environmental Monitoring and Assessment,186,12 (2014)

35. Y.H. Ma, X.F. Wang, W. Wei, Y.F. Qi, T.L. Ii, Chinese Journal of Applied Ecology,16, 11(2005)

36. A. Piotrowska, E. Wilczewski, Geoderma,189190(2012)

37. Y.Y. Wang, F.Z. Wu, X.G. Zhou,China Vegetables, 16,(2009)

38. Y. Tian, J. Liu, X. Zhang, Nutrient Cycling in Agroecosystems, 88,3(2010) 